\title{
Determinants of Entrepreneurial Attitudes in Relation to Students of Economics and Non-Economics
}

\author{
Monika Jakubiak*, Krystyna Buchta**
}

The issue of entrepreneurship has become extremely popular in recent years. The reason behind the phenomenon ought to be seen in the growing significance of entrepreneurship in the development of modern economies, emphasis on competence development and individuals' activity. The literature of the subject discusses academic entrepreneurship with growing frequency. The issue is associated with the changing role of the modern university. At present, universities are becoming the place where students' attitudes and competences are shaped in the context of challenges posed by the increasingly competitive labor market and innovative economy. The subject matter of the present paper pertains to entrepreneurial competences and attitudes of students representing selected university courses. The objective of the paper is to identify entrepreneurial competences and factors determining pro-entrepreneurial attitudes of respondents. The authors attempt to evaluate students' readiness to undertake vocational activities, especially these associated with self-employment. The study allowed a comparative analysis of respondents' competences and attitudes with regard to entrepreneurial activities to be conducted. The following research questions were posed: Do the students of the assessed university courses in economy who are considered more inclined and predestined to establish a business feel more prepared to do so and declare higher entrepreneurial competences than remaining respondents? Does the particular course of studies determine the decision pertaining to becoming self-employed?

Keywords: entrepreneurial education, students' entrepreneurial attitudes, entrepreneurial competences, students of economics and non-economics.

Submitted: 22.08.2016 | Accepted: 06.11.2016

\section{Determinanty postaw przedsiębiorczych studentów kierunków ekonomicznych i nieekonomicznych}

Pojęcie przedsiębiorczości stato się $w$ ostatnich latach niezmiernie popularne. Przyczyn tej sytuacji należy upatrywać m.in. we wzrastajacej roli przedsiębiorczości w rozwoju wspótczesnych gospodarek, nacisku na rozwój kompetencji i aktywność jednostek. Przedsiębiorczość

\footnotetext{
"Monika Jakubiak - PhD, Maria Curie Skłodowska University in Lublin, Faculty of Economics, Institute of Management.

Mailing address: Maria Curie Skłodowska University in Lublin, Faculty of Economics, Institute of Management, Pl. M. Curie-Skłodowskiej 5, 20-031 Lublin.

** Krystyna Buchta - PhD, Józef Piłsudski University of Physical Education in Warsaw, Biała Podlaska Branch, Institute of Marketing and Statistics.

Mailing address: Józef Piłsudski University of Physical Education in Warsaw, Biała Podlaska Branch, Institute of Marketing and Statistics, ul. Akademicka 2, 21-500 Biała Podlaska; e-mail: monika.jakubiak@umcs.pl; krystynabuchta@poczta.fm.
}

Ministry of Science
and Higher Education Republic of Poland
The creation of the English-language version of these publications is financed in the framework of contract No. 768/P-DUN/2016 by the Ministry of Science and Higher Education committed to activities aimed at the promotion of education. 
definiowana jako poszukiwanie, tworzenie oraz wykorzystywanie szans może przyjmować wiele postaci. Najczęściej definiowana jako aktywność w kierunku zakładania i prowadzenia wtasnej firmy ma jednak o wiele szerszy wymiar. Może wiazać się z aktywnościa jednostki lub grupy osób, podejmowaniem wielu różnorodnych działań, zarówno w kontekście pracy zawodowej, jak tė̇ życia społecznego.

Coraz czéściej w literaturze przedmiotu podejmowany jest aspekt przedsiębiorczości akademickiej, wiążacy się ze zmieniająca się rola wspótczesnej szkoty wyższej. Uczelnie staja się bowiem aktualnie miejscem ksztattowania postaw $i$ kompetencji studentów $w$ kontekście wyzwań coraz bardziej konkurencyjnego rynku pracy i innowacyjnej gospodarki.

Problematyka prezentowanego opracowania dotyczy kompetencji i podstaw przedsiębiorczych studentów wybranych kierunków studiów. Celem artykutu byta identyfikacja kompetencji przedsiębiorczych oraz czynników determinujacych postawy proprzedsiębiorcze badanych. Autorki podjęty próbę oceny przygotowania studentów do realizacji dziatań zawodowych, w szczególności związanych z podejmowaniem wtasnej działalności. Przeprowadzone badania umożliwity analizę porównawczą kompetencji i postaw respondentów $w$ zakresie przedsiębiorczości. Podjęto próbę uzyskania odpowiedzi na pytanie, czy studenci analizowanych kierunków ekonomicznych, uważani za bardziej predestynowanych do prowadzenia wtasnej firmy, czuja się lepiej przygotowani $w$ tym zakresie i deklaruja wyższe kompetencje przedsiębiorcze niż pozostali badani. Czy można uznać, że kierunek studiów determinuje decyzje dotyczace prowadzenia własnej działalności?

Słowa kluczowe: przedsiębiorczość, postawy przedsiębiorcze studentów, kompetencje przedsiębiorcze, studenci kierunków ekonomicznych i nieekonomicznych.

Nadesłany: 22.08.2016 | Zaakceptowany do druku: 06.11.2016

\section{JEL: L26}

\section{Introduction}

The issue of entrepreneurship has become extremely popular recently. The reason behind the phenomenon ought to be seen in the growing significance of entrepreneurship in the development of modern economies, emphasis on competence development and individuals' activities. Entrepreneurship defined as a search, creation and exploitation of opportunities may assume several forms. However, the most general meaning, interpreted as an activity directed at establishing and managing a business, encompasses a much broader scope. It may be associated with activities of an individual or a group undertaking a variety of tasks both in the context of professions and broadly understood public life.

The current economic situation, difficulties arising on the labor market which result from globalization and intensive technological development, constant requirement for new competences, and the lack of employment for the representatives of the "obsolete" professions and skills, demand of the young a particular attitude and approach.
University graduates, facing a critical transition from education onto the labor market, are in a particularly challenging position. According to experts, a swift transition towards undertaking vocational tasks demands of students a series of competences, both education-relevant (associated with the pursued education) and general (independent from the acquired profession). Education, especially higher one, ought to prepare young people for undertaking vocational tasks as well as business activities. Education for entrepreneurship is becoming one of the key challenges of modern economy (Wach, 2014).

The subject matter of the present study pertains to the comparative analysis of factors determining students' entrepreneurial intentions and attitudes. Empirical studies were conducted among students of economics (business accounting and finance, abbrev. BAF), who, due to the profile of the course, are considered more inclined and predestined to manage an own business (Kraśnicka, Głód, Ludvik and Peterkova, 2014; Marszałek, 2012). When searching for factors determining entrepreneurial attitudes, results were compared with opin- 
ions of non-economics students (Physical Education, abbrev. PE). Such a course was selected due to the fact that the sports market segment has become an attractive area for becoming self-employed. This is a consequence of a growing interest in one's own health, physical fitness and appearance related to a particular lifestyle, and public perception of sport as an interesting media event (Starakiewicz and Kubów, 2014).

\section{The Subject Matter and Related Literature}

The issue of entrepreneurship currently attracts attention of experts from several fields. Therefore, an unequivocal definition of the term, approached from the perspective of economics, social studies, and psychology, is difficult to find. According to S. Kwiatkowski, entrepreneurship revolves around creating material wealth from non-material resources (Kwiatkowski, 2000). The role of an entrepreneur, a person pursuing opportunities, able to identify and exploit them, accumulate and organize resources, take risks, and implement innovations, seems critical (Shane, 2003; Shane and Venkataraman, 2000; Glinka and Gudkova, 2011).

Social and economic changes are usually accompanied by changes in entrepreneurs' interests. New forms of entrepreneurship emerge, others become obsolete. At present, entrepreneurship which verges on the border of science and business is experiencing rapid development. In addition, new forms of intellectual, technological, and knowledge entrepreneurship emerge (Cieślik et al., 2011).

With growing frequency, the literature of the subject discusses the issue of academic entrepreneurship associated with the changing role of the modern university. At present, universities are becoming the place where students' attitudes and competences are shaped in the context of challenges posed by the increasingly competitive labor market and innovative economy. The role of the university is not only to educate human resources, but also to develop multifunctional relations with their environment - business entities, institutions, local and national governments (Binkauskas, 2012; Osiri and McCarty, 2013; Cieślik et al., 2011). As a result of the cooperation, the modern university is traversing beyond its contemporary role. Apart from education and research, it shapes students' and employees' entrepreneurial attitudes, and enables them to function on the market independently. This is the essence of proinnovative education associated with the development of individual creative skills and the preparation of students for becoming a part of innovative organizational cultures (Shattock, 2005; Laukkanen, 2003).

Challenges of globalization determine the current strategic directions of education development in its practical aspect. Modern education ought to focus on imparting skills for independent activity, and shape skills enabling swift self-organization and entrepreneurial adaptation to changing environment. Moreover, it ought to be open to the opportunity of swift exploitation of the academia's (students, graduates, the faculty) creativity, which contributes to innovation in economy (Okoń-Horodyńska, 2008). Modern global education denotes education for innovation addressing knowledge-based society which embraces any novelty. Currently, innovation, entrepreneurship and creativity, constituting the basis for competitive business edge in knowledge-based economy, have become the most critical challenges for education, especially of the higher type (Cieślik et al., 2011).

Modern economy demands of graduates particular competences associated not only with knowledge and skills connected with the particular university course. Studies constitute a significant period when young people develop themselves, their competences, and at the same time shape the basis for their professional career. In turbulent times of changes on the labor market, specific competences are expected of the young, especially with regard to activity, flexibility, openness to change, and dealing with the ever-changing reality. These competences are associated with entrepreneurship considered as the characteristic of a pro-active individual focused on development, and search for and exploitation of opportunities emerging in the surrounding environment.

The present paper tackles the issue of shaping students' entrepreneurial competences. The literature of the subject emphasizes the need for shaping graduates' attitudes and competences in the framework of university studies (Targalski, 
2003; Shattock, 2005; Wach, 2014; Safin, 2014). The familiarity with determinants which foster individuals' entrepreneurial activities seems critical in the development of university curricula (Kurczewska, 2010).

The issue of entrepreneurial intentions, interpreted as an individual's internal feeling regarding the establishment of an own business, which may result in becoming self-employed in the future, constitutes a significant theme in the study of entrepreneurship (Pawlak, 2015; Tomski, 2015; Zbierowski, 2014). Therefore, the identification of factors impacting students' entrepreneurial intentions and attitudes, and the assessment of the university's role in the process, seem crucial (Safin, 2014).

Students' competences and entrepreneurial intentions have become of interest for researchers in Poland and abroad (Kuehn, 2008; Marszałek, 2012; Zbierowski, 2014; Kraśnicka, Głód, Ludvik and Peterkova, 2014; Rachwał and Wach, 2016). Young people who will be graduating and entering the labour market shortly ought to be supported in their transition. Due to considerable unemployment among the young and an insufficient number of satisfactory positions for university graduates becoming an entrepreneur may offer an interesting alternative.

The present paper focuses on entrepreneurial competences and determinants of respondents' pro-entrepreneurial intentions and attitudes.

On the basis of the literature survey, the premise that the process of shaping entrepreneurial intentions and attitudes is a result of particular features of an individual, personality traits, values, attitudes, competences, motivations, the individual's training (both in the process of education and experiences), and the influence of the surrounding environment (e.g. growing up in an entrepreneurial family) was made (Glinka and Gudkova, 2011; Olearnik, 2007; Kwiatkowski, 2000).

A particular role in the process of fostering entrepreneurial attitudes is ascribed to education, including higher one. The academia ought to support students by preparing them for establishing their own businesses, encouraging them to put their ideas into practice, follow actions of experienced entrepreneurs and undertake a variety of activities in the course of studies.
Risk-taking is an inherent part of entrepreneurship, which frequently results in failures. In addition, supporting students and promoting entrepreneurial attitudes demand indication of success factors and business development opportunities (Targalski, 2003; Olearnik, 2007; Brzozowska, Glinka and Postuła, 2014).

Several characteristics of students' entrepreneurial intentions, e.g. plans for establishing a business, evaluation of consequences of becoming self-employed, competences required for undertaking own initiatives, and inclination towards undertaking a variety of extra-curricular activities, were analyzed in the present study.

\section{Methodology}

The objective of the study was to identify entrepreneurial competences and determinants of respondents' pro-entrepreneurial attitudes.

Empirical studies were conducted by means of a diagnostic poll method with a random survey technique. The study was conducted in 2015/16 academic year among 327 students of full-time graduate studies at two universities in Lublin Voivodeship:

- Maria Curie-Skłodowska University,

Faculty of Economics, Business Accounting and Finance course (abbrev. BAF);

- Józef Piłsudski University of Physical

Education in Warsaw, Biała Podlaska branch, Faculty of Tourism and Health, Physical Education course (abbrev. PE).

Sampling was purposive and exhaustive. All students participating in the didactic process at the time of the study completed the questionnaire.

The questionnaire consisted of two content-related sections and a personal data section for demographics. The first section pertained to respondents' opinions regarding the establishment and management of an own business. Students were also requested to indicate extra-curricular activities they pursued, and experiences gained.

The second section pertained to competences. The literature of the subject divides competences into general (independent from the course of studies and curriculum) and education-relevant (associated with courses and knowledge of the subject of studies) (Tuning, 2006). The present study 
attempted to evaluate the level of selected general competences considered as the determinants of respondents' entrepreneurial competences. Respondents were also requested to assess the significance of the competences in their prospective career. A 4-point scale was applied (1 very low level, 4 - very high level).

Table 1 presents the structure of the sample with regard to independent variables. The sample was slightly dominated by respondents studying business accounting and finance $(52 \%)$. Women dominated in the sample $(57 \%)$. The fact that the structure of respondents' sex significantly varied depending on the particular course is noteworthy. The structure of BAF course was dominated by women, constituting $80 \%$ of the group, whereas in the PE course, they constituted the minority (31\%).

The majority of respondents were unemployed in the period the study was conducted $(71 \%)$. The structure was similar for both analyzed courses. Probably, it is a result of the particular character of these studies, as all respondents studied full-time.

The majority of respondents stated their place of residence as a village $(55 \%)$, which may be a consequence of the region being agricultural in character. The majority of respondents evaluate their financial standing as average (55\%), and only $4 \%$ as difficult.

The analysis of respondents' answers regarding their grade average revealed

Table 1. Respondents' structure

\begin{tabular}{|c|c|c|c|c|c|c|c|}
\hline \multirow{2}{*}{\multicolumn{2}{|c|}{ Classification Criterion }} & \multicolumn{2}{|c|}{ BAF } & \multicolumn{2}{|c|}{ PE } & \multicolumn{2}{|c|}{ Total } \\
\hline & & \multirow{2}{*}{$\frac{\mathbf{N}}{137}$} & \multirow{2}{*}{$\begin{array}{l}\% \\
80\end{array}$} & \multirow{2}{*}{$\frac{\mathbf{N}}{49}$} & \multirow{2}{*}{$\begin{array}{l}\% \\
31\end{array}$} & \multirow{2}{*}{$\frac{\mathbf{N}}{186}$} & \multirow{2}{*}{$\begin{array}{l}\% \\
57\end{array}$} \\
\hline \multirow{3}{*}{ Sex } & Females & & & & & & \\
\hline & Males & 33 & 19 & 98 & 63 & 131 & 40 \\
\hline & N/A & 1 & 1 & 9 & 5 & 10 & 3 \\
\hline \multirow{3}{*}{$\begin{array}{l}\text { Professional } \\
\text { situation }\end{array}$} & Employed & 39 & 23 & 48 & 31 & 87 & 27 \\
\hline & Unemployed & 132 & 77 & 101 & 65 & 233 & 71 \\
\hline & N/A & 0 & 0 & 7 & 4 & 7 & 2 \\
\hline \multirow{3}{*}{$\begin{array}{l}\text { Place of } \\
\text { residence }\end{array}$} & City & 67 & 39 & 72 & 46 & 139 & 43 \\
\hline & Village & 104 & 61 & 77 & 49 & 181 & 55 \\
\hline & N/A & 0 & 0 & 7 & 4 & 7 & 2 \\
\hline \multirow{4}{*}{$\begin{array}{l}\text { Financial } \\
\text { standing }\end{array}$} & Good & 71 & 42 & 57 & 37 & 128 & 39 \\
\hline & Average & 95 & 56 & 86 & 55 & 181 & 55 \\
\hline & Difficult & 5 & 3 & 8 & 5 & 13 & 4 \\
\hline & $\mathrm{N} / \mathrm{A}$ & 0 & 0 & 5 & 3 & 5 & 2 \\
\hline \multirow{5}{*}{$\begin{array}{l}\text { Grade } \\
\text { average }\end{array}$} & below 3,5 & 16 & 9 & 31 & 20 & 47 & 14 \\
\hline & $<3.5-4.0)$ & 73 & 43 & 58 & 37 & 131 & 40 \\
\hline & $<4.0-4.5)$ & 63 & 37 & 40 & 26 & 103 & 31 \\
\hline & 4.5 and above & 19 & 11 & 22 & 14 & 41 & 13 \\
\hline & N/A & 0 & 0 & 5 & 3 & 5 & 2 \\
\hline
\end{tabular}

Legend: N/A - no data available.

Source: the authors' findings on the basis of the poll. 
that those in the final year of their studies scored 3.5-4.0 (40\%) the most frequently. The second position was occupied by those scoring 4.1-4.5 (32\%). The fact that a higher grade average was achieved by BAF students, $48 \%$ of whom scored 4.1-4.5, is worth mentioning. In the case of PE students, similar results were declared by $40 \%$ of respondents.

\section{Students' Entrepreneurial Intentions - Results of Empirical Studies}

The literature of the subject highlights that a positive attitude towards entrepreneurship determines particular decisions regarding self-employment being made (Kurczewska, 2010). Entrepreneurial attitudes may be manifested e.g. by intentions associated with establishing and managing an own business. Therefore, respondents were requested to state whether they intended to establish a business where they would exploit their professional knowledge acquired in the course of their studies.

Figure 1 presents respondents' declarations associated with the intention of becoming self-employed.

When analyzing respondents' answers regarding the intention, the fact that they have not made a final decision yet can be highlighted. The greatest number of respondents answered "I do not know" to
Figure 1. Declarations regarding the intention of becoming self-employed (data in \%; $n=327$ )

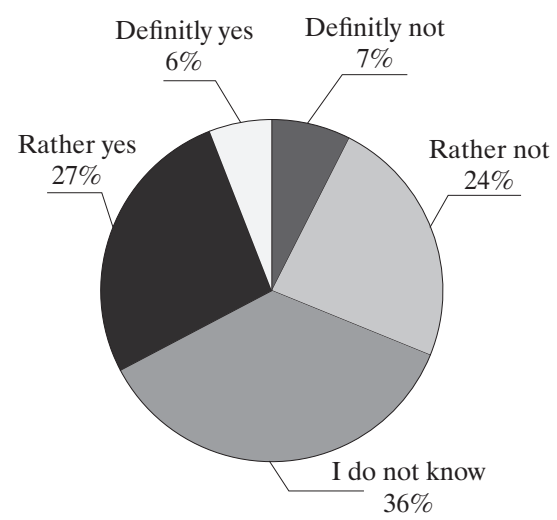

Source: the authors' own findings.

this question. Positive answers with regard to the intention ("Definitely yes", "Rather yes") amounted to $33 \%$. The number of people expressing the decision to both start a business and not to become involved in self-employment amounted to a few percent of respondents.

Figure 2 presents the comparison of answers for both respondent groups regarding the question on the intention of becoming self-employed. No statistically significant differences were established. However, a tendency for PE students to declare positive answers was observed.

Figure 2. The comparison of answers for both respondent groups regarding the question on the intention of becoming self-employed (data in \%)

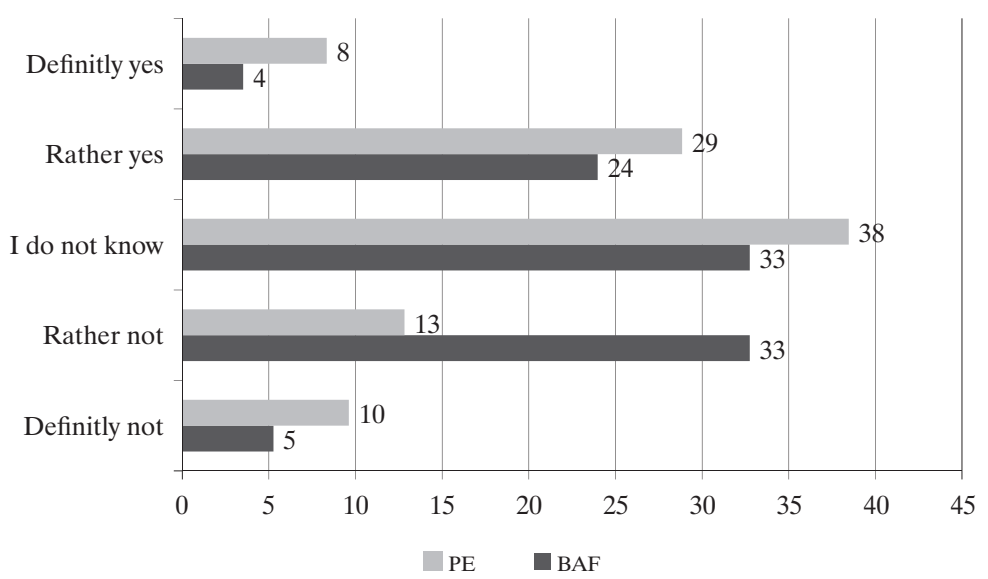

Source: the authors' own findings. 
Respondents who intended to establish a business were requested to indicate a period of time they would register their companies in. Similarly, the most frequent answer in this case was "I do not know" (selected by $56 \%$ of respondents). A further group of respondents indicated a 2 year's period (35\%). Almost $10 \%$ indicated the period of 1-2 years counting from the date of the study. The declaration of the time perspective was not diversified with regard to the university course.

Regardless of their plans for establishing a business, respondents were requested to assess the consequences of becoming self-employed. Statistically significant differences were observed in 6 out of 9 aspects (Fig. 3). Respondents representing BAF indicated apprehension with regard to risk-taking (93\% vs. 67\%), the feeling of stress $(87 \%$ vs. $65 \%)$, severe restriction of free time ( $81 \%$ vs. $64 \%)$, and the risk of financial loss (56\% vs. $30 \%)$ more frequently than the remaining respondents. At the same time, students of BAF were more willing to admit that selfemployment gives more satisfaction than a full-time job for someone else (91\% vs. $82 \%)$. On the other hand, PE students indicated the opportunity for developing their academic interests as a result of man- aging an own company much more frequently than the other respondents $(67 \%$ vs. $46 \%$ ).

\section{Undertaken Activities as Determinants of Respondents' Entrepreneurial Attitudes}

The literature of the subject highlights the relationship of entrepreneurship with activity, openness to new experiences, and undertaking new challenges (Glinka and Gudkova, 2011). An active behavior of an individual in the process of developing students' entrepreneurial potential seems particularly important. Undertaking activities with a view to gaining additional professional experience prior to graduating significantly improves chances of finding employment and contributes to achieving professional success and further career development (Cybal-Michalska, 2014).

The present study attempts to evaluate the frequency of activities undertaken as an opportunity for gaining relevant competences and professional experience (including that in the area of entrepreneurship). Empirical analyses of the declared activities indicated that vocational activity undertaken by the greatest number of respondents was student internships (approx. 80\%; Tab. 2). The internships were undertaken

Figure 3. Consequences of self-employment (data in \%; statistically significant differences, $p<0.05)$

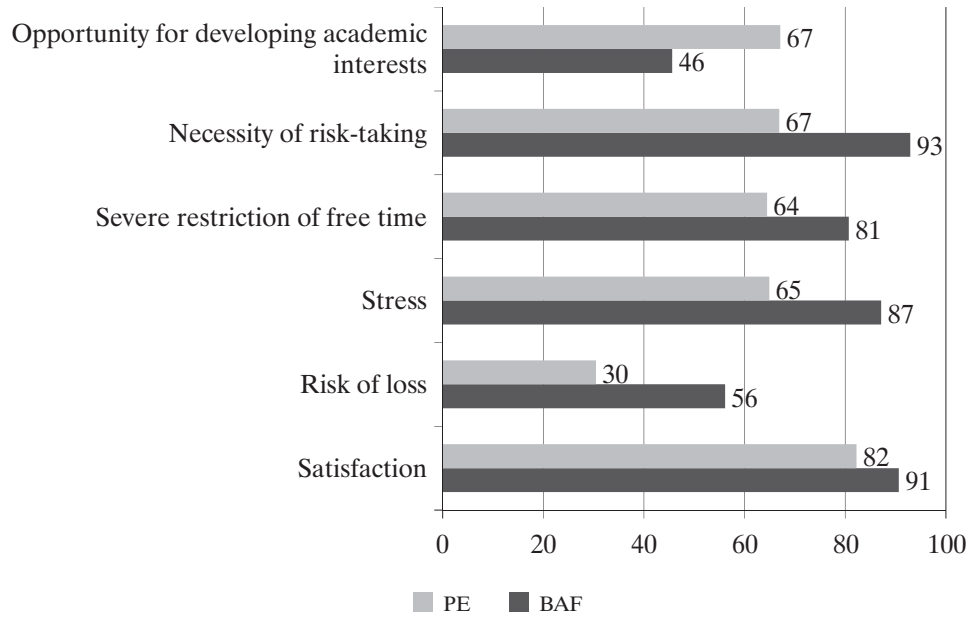

Notes: only the highest scores were taken into account $(4+5$, scale $1-5)$.

Source: the authors' own findings.

Wydział Zarządzania UW DOI 10.7172/1733-9758.2016.21.2 
Table 2. Experiences gained in the course of studies (data in \%)

\begin{tabular}{|l|c|c|c|c|c|}
\hline \multicolumn{1}{|c|}{ Specification } & $\begin{array}{c}\text { Total } \\
(\mathbf{N = 3 2 7})\end{array}$ & $\begin{array}{c}\text { BAF } \\
(\mathbf{N = 1 7 1})\end{array}$ & $\begin{array}{c}\text { PE } \\
(\mathbf{N = 1 5 6 )}\end{array}$ & $\mathbf{X 2}$ & Cramer's V \\
\hline Student internships in Poland* & 85 & 91 & 78 & 9 & 0.17 \\
\hline International student internship & 3 & 2 & 5 & 2.9 & 0.09 \\
\hline Summer work in Poland & 45 & 40 & 51 & 3.5 & 0.10 \\
\hline Summer work abroad* & 19 & 14 & 24 & 5.1 & 0.12 \\
\hline Voluntary work* & 20 & 15 & 26 & 6.2 & 0.14 \\
\hline Internships & 18 & 15 & 22 & 2.8 & 0.09 \\
\hline Work in a family business & 12 & 13 & 11 & 0.5 & 0.04 \\
\hline
\end{tabular}

Notes: * - statistically significant differences; Results do not total 100\%, several answers could be selected.

Source: the authors' own findings.

by BAF students more frequently than PE students (91\% vs. $78 \%)$. A further form of experience gaining was summer jobs in Poland $(45 \%)$. Every fifth respondent acted as a volunteer. In the case of PE students, every fourth of them undertook such an activity.

Summer jobs abroad were declared less frequently (19\%). In this case, it was PE students who undertook such an activity more frequently (24\% PE students vs. $14 \%$ BAF). Only $18 \%$ of the total number of respondents participated in an extra-curricular internship program.

Individuals' vocational potential development is also influenced by the undertaken extra-curricular activities. Polish universities offer numerous opportunities for pursuing one's interests. Several training and counseling institutions offering services dedicated to students function in the university environment.

Table 3 presents students' activities undertaken in the course of studies. More

Table 3. Forms of respondents' activities (data in \%)

\begin{tabular}{|l|c|c|c|c|c|}
\hline \multicolumn{1}{|c|}{ Specification } & $\begin{array}{c}\text { Total } \\
(\mathbf{N = 3 2 7})\end{array}$ & $\begin{array}{c}\text { BAF } \\
(\mathbf{N = 1 7 1 )}\end{array}$ & $\begin{array}{c}\text { PE } \\
(\mathbf{N = 1 5 6})\end{array}$ & $\mathbf{X 2}$ & $\begin{array}{c}\text { Cramer's } \\
\text { V }\end{array}$ \\
\hline Erasmus internship/exchange & 2.4 & 2.3 & 2.6 & 0.0 & 0.00 \\
\hline Soft skills trainings/courses & 32.4 & 30.4 & 34.6 & 0.7 & 0.05 \\
\hline Hard skills trainings/courses* & 55.7 & 47.4 & 64.7 & 10.0 & 0.17 \\
\hline $\begin{array}{l}\text { Involvement in students } \\
\text { government* }\end{array}$ & 7.0 & 2.3 & 12.2 & 12.9 & 0.20 \\
\hline $\begin{array}{l}\text { Involvement in academic } \\
\text { science clubs* }\end{array}$ & 14.4 & 9.4 & 19.9 & 7.4 & 0.15 \\
\hline $\begin{array}{l}\text { Involvement in Academic } \\
\text { Sports Association* }\end{array}$ & 15.6 & 8.8 & 23.1 & 12.9 & 0.20 \\
\hline $\begin{array}{l}\text { Involvement in institutions } \\
\text { outside the academia* }\end{array}$ & 19.6 & 7.6 & 32.7 & 34.2 & 0.32 \\
\hline
\end{tabular}

Notes: * - statistically significant differences; Results do not total $100 \%$, several answers could be selected. Source: the authors' own findings. 
Figure 4. Relevance of competences in prospective careers (statistically significant differences, $p<0.05)$

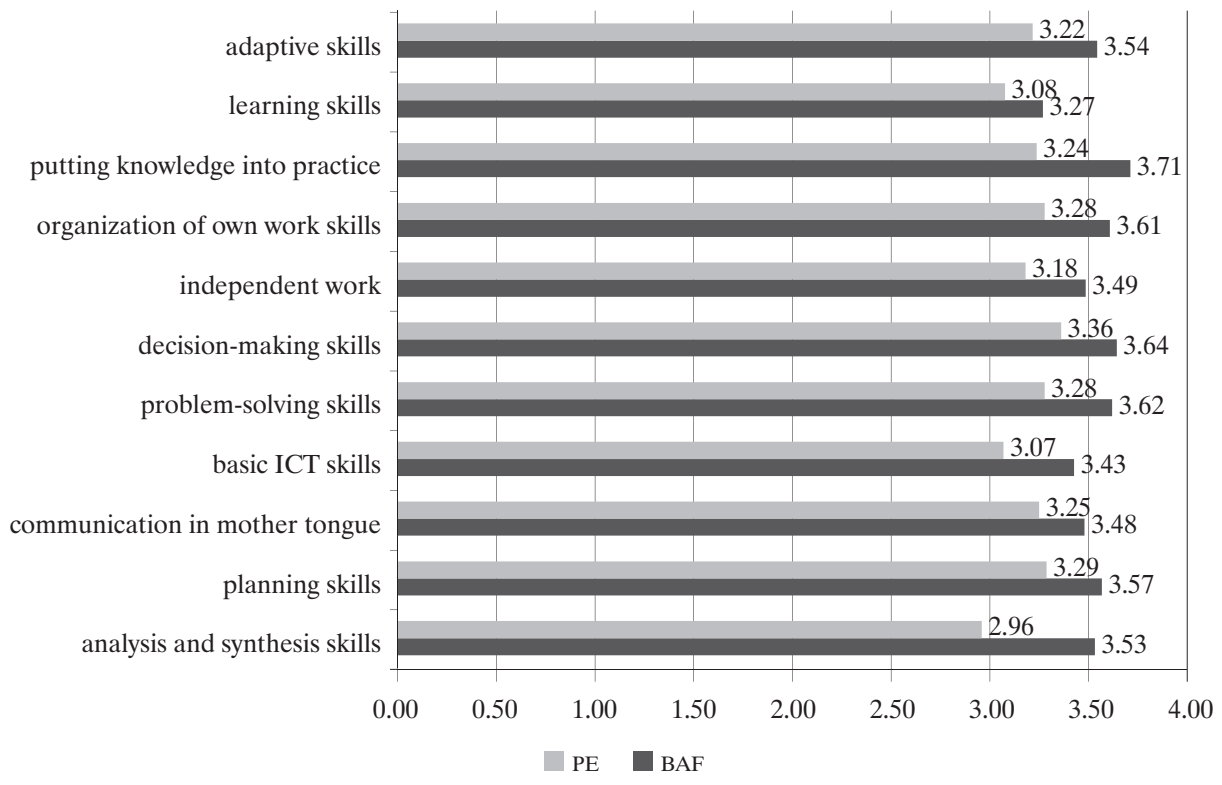

Notes: scale from $1=$ very low level to $4=$ very high level; commas denote decimals.

Source: the authors' own findings.

than half of respondents $(56 \%)$ participated in trainings developing vocational competences. Every third participated in courses developing soft competences. Every fifth respondent was a member of extra-mural organizations. The activity within the Academic Sports Association $(16 \%)$ and science clubs (14\%) was declared less frequently.

In the case of 5 out of 7 extra-curricular activities statistically significant differences were observed. The five activities were undertaken by PE students more frequently.

\section{Respondents' Competences as Determinants of Entrepreneurial Attitudes}

When searching for factors determining respondents' plans regarding becoming self-employed, attention was drawn to the level of competences facilitating the emergence of entrepreneurial attitudes and the significance of these competences in prospective careers. The comparative analysis of answers in both respondent groups with regard to the significance of the competences in prospective careers indicated statistically significant differences in 11 out of $18(61 \%)$ aspects. BAF students' answers scored higher (Fig. 4).

According to respondents, the most significant competences include the application of knowledge in practice (average 3.71 on a 4-point scale for BAF students, and 3.24 for PE students), decision-making skills (3.64 vs. 3.66), problem solving (3.62 vs. 3.28), and the organization of own work (3.62 vs. 3.28). The remaining competences were evaluated slightly lower. The majority of these scored 3 points and above on a 4-point scale.

The ranking of competences gained in the course of studies as perceived by respondents is considerably different. Statistically significant differences emerged in 11 out of 18 competences, but only in one case (spoken and written communication in Polish) these were in favor of BAF students (average 3.19 vs. 2.75). In the remaining 10 cases, PE students assessed themselves significantly higher (Fig. 5). The highest scores were observed with regard to com- 
Figure 5. Self-assessment of competences acquired in the course of studies (statistically significant differences, $p<0.05)$; commas denote decimals.

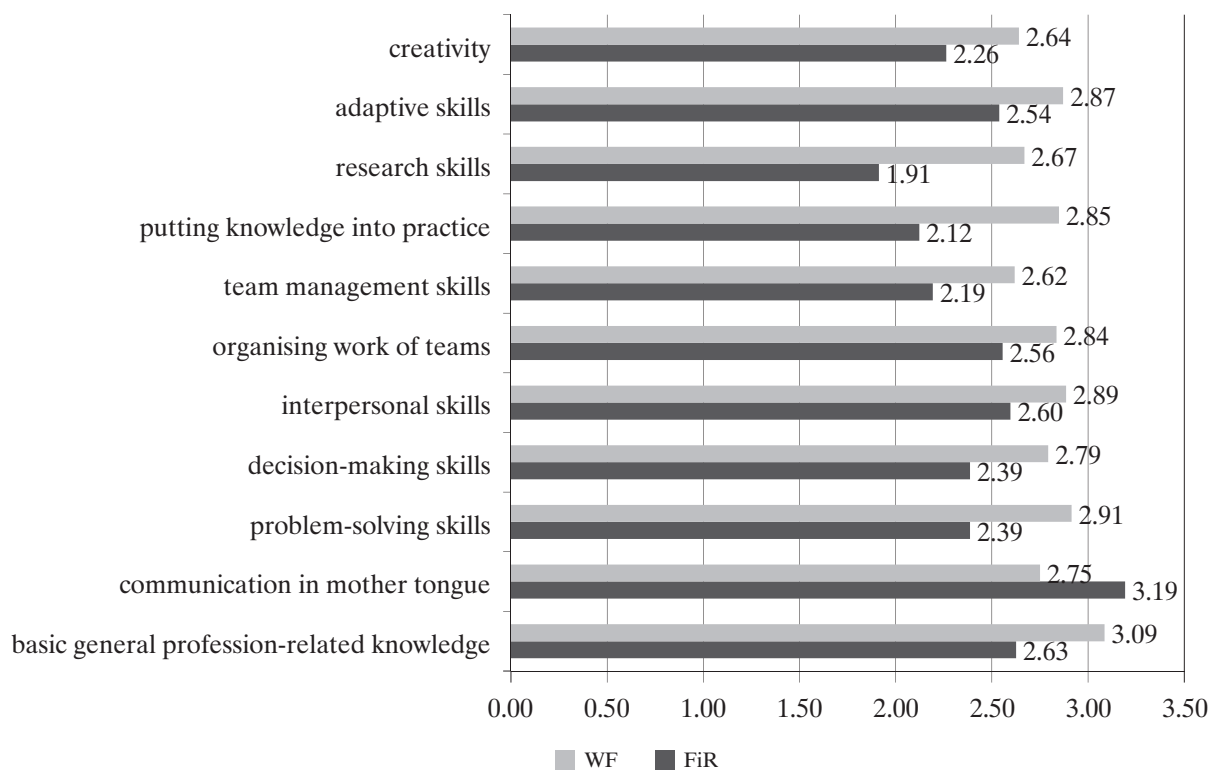

Notes: scale from $1=$ very low level to $4=$ very high level.

Source: the authors' own findings.

petences which may be considered as PE students" "strengths". The scores pertained to the general knowledge in the field of a particular profession (average 3.09 for $\mathrm{PE}$ students vs. 2.63 for BAF students), problem solving (2.91 vs. 2.39), interpersonal skills (2.89 vs. 2.60), and adaptive skills (2.87 vs. 2.54)

The lowest scores were observed as far as research skills are concerned (average for BAF - 1.91). These skills scored rather high with PE students (2.67). BAF students evaluated their skills in putting knowledge into practice slightly higher than the previous skill (2.12). Interestingly, they considered the skill as the most critical in their prospective professions.

In globalization of the labor market, language skills are undeniably among graduates' required competences. Respondents assessed their skills in English the highest (2.92 on a 4-point scale). The selfassessment was not diversified as far as the course of studies is concerned. Skills in other languages scored significantly lower.

An attempt at evaluating the impact of the evaluated competences upon plans for self-employment was also made. As a consequence, a series of correlation coefficients was calculated (Tab. 4). The analysis of the correlation matrix indicated statistically significant relationships only in the case of PE students. The relationship pertained to merely 3 out of 18 competences: analysis and synthesis, organization of own work, and learning. The high level of the first competence (analysis and synthesis) was frequently associated with plans for self-employment. A reverse phenomenon was observed with regard to the organization of own work, and learning. In the case of these competences, their high level was associated with low interest in managing an own business in the future.

\section{Discussion}

The issue of entrepreneurial education at the university level was reflected in the present paper. In order to establish determinants of students' entrepreneurial attitudes, opinions of economics students (business accounting and finance) were analyzed and compared with the opinions expressed by the representatives of non- 
Table 4. Correlation coefficients between the level of competences gained and respondents' declarations for self-employment

\begin{tabular}{|c|c|c|c|c|}
\hline No. & Specification & $\begin{array}{c}\text { Total } \\
(\mathbf{N}=\mathbf{3 2 7})\end{array}$ & $\begin{array}{c}\text { BAF } \\
(\mathbf{N}=171)\end{array}$ & $\begin{array}{c}P E \\
(N=156)\end{array}$ \\
\hline 1 & analysis and synthesis skills & 0.04 & -0.11 & 0.17 \\
\hline 2 & planning skills & -0.01 & -0.08 & -0.01 \\
\hline 3 & basic general profession-related knowledge & 0.06 & -0.01 & 0.05 \\
\hline 4 & communication in mother tongue & 0.03 & 0.10 & 0.05 \\
\hline 5 & basic ICT skills & -0.01 & 0.05 & -0.07 \\
\hline 6 & problem-solving skills & 0.01 & 0.02 & -0.12 \\
\hline 7 & decision-making skills & 0.04 & 0.08 & -0.10 \\
\hline 8 & interpersonal skills & -0.01 & 0.07 & -0.16 \\
\hline 9 & groupwork skills & -0.03 & -0.03 & -0.03 \\
\hline 10 & independent work & 0.06 & 0.04 & 0.10 \\
\hline 11 & organization of own work skills & -0.10 & 0.02 & -0.22 \\
\hline 12 & organizing work of teams & 0.05 & 0.09 & -0.05 \\
\hline 13 & team management skills & 0.07 & 0.12 & -0.06 \\
\hline 14 & putting knowledge into practice & 0.09 & 0.04 & 0.01 \\
\hline 15 & research skills & 0.00 & -0.13 & -0.02 \\
\hline 16 & learning skills & -0.11 & -0.04 & -0.18 \\
\hline 17 & adaptive skills & -0.01 & -0.05 & -0.05 \\
\hline 18 & creativity & 0.01 & 0.05 & -0.09 \\
\hline
\end{tabular}

Source: the authors' own findings.

economics studies (physical education). The premise was made that the curriculum of studies in economics pertains to issues facilitating the establishment and management of an own business much more frequently than in the case of other types of studies. Such a comparison enabled answers to the research question pertaining to the envisaged influence of the type of studies upon entrepreneurial intentions and competences to be obtained.

The study proved, contrary to the authors' expectations, a lack of statistically significant differences between declarations of both respondent groups with regard to plans for self-employment. A positive answer regarding self-employment was given by almost every third respondent.
Answers in this respect are similar to results present in the literature of the subject. The interest in becoming selfemployed was voiced by a similar percentage of students of economics (approx. 40\%) (Marszałek, 2012; Zbierowski, 2014; Kraśnicka, Głód, Ludvik and Peterkova, 2014).

The fact that a similar number of respondents $(36 \%)$ was undecided at the time of the study as far as the issue is concerned is noteworthy. Interestingly, a greater degree of decisiveness ought to be expected from students of graduate courses at this particular stage of education. The undecided respondents will make their choice depending on the market situation and employment opportunities. Therefore, 
their self-employment is perceived as an alternative to a full-time job. Such an attitude is a determinant of neither innovative nor creative entrepreneurship, but rather a forced entrepreneurship.

The analysis of respondents' opinions with regard to the consequences of being self-employed indicated that those with a background in economics are more frequently aware of the fact that it demands effort and poses financial, psychological and social risks.

Results in this area are also convergent with conclusions of previous studies and opinions expressed in the literature. Students of economics, due to their curriculum, possess more extensive knowledge on self-employment and are more aware of consequences it entails (Jakubiak and Buchta, 2015; Jakubiak and ChmielewskaMuciek, 2015; Kraśnicka, Głód, Ludvik and Peterkova, 2014).

Therefore, entrepreneurial education ought to be directed at offering methods of managing such difficulties, which are an inseparable element of self-employment in the changing socio-economic environment.

The development of an individual's professional potential is determined by any vocational and extra-vocational activities undertaken in the course of studies. The analysis of the compiled empirical data indicated that the most frequent activity undertaken by respondents were various types of internships, selected by more than $80 \%$ of the total. This is undeniably a positive result, due to the fact that in light of previous studies (Jakubiak and MazurSokól, 2015), in the opinion of employers themselves, student internships belong to the most effective recruitment strategies. When employing interns, employers have the opportunity of assessing their aptitude for prospective recruitment and employment. In order for internships to be effective, young people ought to take full advantage of and display their strengths and skills.

Student internships were the only activity undertaken by BAF students significantly more frequently than by the remaining respondents. In the case of the other activities with regard to which differences were observed (i.e. summer work abroad, voluntary work, involvement in students' government, involvement in academic science clubs, involvement in Academic
Sports Association, involvement in institutions outside the academia) PE students declared being involved in these significantly more frequently than the remaining respondents. This may be a result of the character of studies - BAF is much more time-consuming and features considerably more classes, including those which demand preparation. On the other hand, it is a university course which offers more prospective opportunities. Currently, the financial sector (including accounting, banking, insurance, taxes, etc.) is considered as the one offering the most growth, thus creating the greatest number of employment opportunities (Salary Report, 2016). In turn, the situation of PE graduates on the labor market is much more difficult. The greatest number of them seek employment in the education sector, which does not generate as many employment opportunities as required to accommodate all students who annually enter the market. By becoming familiar with such prognoses, students may undertake various activities prior to graduating, develop competences opening prospects other than the acquired profession.

When searching for determinants of respondents' entrepreneurial intentions and attitudes, the level of acquired competences declared by them is noteworthy. The correlation coefficients calculated for the dependent variable (the declaration of prospective self-employment) and the independent variable (the level of acquired competences) proved to be statistically significant in merely three cases, which were associated with PE students. First of all, the analysis and synthesis proved to stimulate students' entrepreneurial attitudes. Next, people who assessed their skills in the organization of own work and learning skills as high were less interested in becoming self-employed in the future.

\section{Conclusions}

Entrepreneurship, apart from innovation and creativity, is considered one of the three pillars of knowledge-based economy. Shaping the knowledge-based society is associated with the necessity of developing human resources able to make decisions, responsibility, initiating and undertaking new, decisive actions. Education, especially higher education, plays a critical role in the 
process. Entrepreneurship may be realized in any sphere of economy, thus may be connected with graduates of various university courses.

The present study was to identify entrepreneurial attitudes and determinants influencing respondents' entrepreneurial intentions. The course of studies and independent variables characterizing respondents, such as sex, age and place of residence, were of particular interest in the analysis.

A more in-depth study which would evaluate other determinants of entrepreneurial attitudes, e.g. entrepreneurial family background, sensitivity to opportunities emerging in the surrounding environment, respondents' attitude towards becoming self-employed, would surely be worthwhile. Conclusions drawn from such a study would offer a deeper analysis of students' entrepreneurial intentions and build recommendations for education in entrepreneurship.

\section{References}

Binkauskas, G. (2012). Academic entrepreneurship: Barriers and fears versus wishes and opportunities. International Journal of Technology Management \& Sustainable Development, 11(3), 231-244.

Brzozowska, A., Glinka, B. and Postuła, A. (2014) Rola uniwersytetu w kształtowaniu postaw przedsiębiorczych. Horyzonty Wychowania, 13(26), 51-72.

Cieślik, J., Matusiak, K.B., Guliński, J. and SkalaPoźniak, A. (2011). Edukacja dla przedsiębiorczości akademickiej. Poznań-Warszawa: Polska Agencja Rozwoju Przedsiębiorczości.

Cybal-Michalska, A. (2014). Proaktywność w karierze jako narzędzie inwestycji i odnawialności kapitału kariery młodzieży akademickiej. Rocznik Pedagogiczny, 37, 93-107.

Glinka, B. and Gudkova, S. (2011). Przedsiębiorczość. Warszawa: Wolters Kluwer business.

Jakubiak, M. and Chmielewska-Muciek, D. (2015) Academic Entrepreneurship's Growth Perspectives in the Opinion of Researchers and Students, Managing Intellectual Capital and Innovation for Sustainable and Inclusive Society. Proceedings of the MakeLearn and TEEM Join Conference 2015, ToKnowPress, 1621-1629.

Jakubiak, M. and Buchta, K. (2015). Postawy przedsiębiorcze studentów wybranych uczelni Lubelszczyzny a rozwój przedsiębiorczości akademickiej. Studia i Materiały Wydziatu Zarzqdzania UW, 2(19), 148-156.
Jakubiak, M. and Mazur-Sokól, A. (2015). Mechanizm rozwoju kariery. Vademecum absolwenta. Lublin: Politechnika Lubelska.

Kraśnicka, T., Głód, G., Ludvik, L. and Peterkova, J. (2014). Uwarunkowania intencji przedsiębiorczych studentów uczelni ekonomicznych Polski i Czech. Przedsiębiorczość - Edukacja, 10, 316-332.

Kuehn, K.W. (2008). Entrepreneurial Intensions Research: Implications for Entrepreneurship Education. Journal of Entrepreneurship Education, 11, 87-98.

Kurczewska, A. (2010). Problemy pomiaru intencji przedsiębiorczych. E-mentor, 4(34). Retrieved from http://www.e-mentor.edu.pl/artykul/index/ numer/36/id/768 (10.07.2016).

Kwiatkowski, S. (2002). Przedsiębiorczość intelektualna. Warszawa: Wydawnictwo Naukowe PWN.

Laukkanen, M. (2003). Exploring academic entrepreneurship: Drivers and tensions of universitybased business. Journal of Small Business and Enterprise Development, 10(4), 372-382.

Marszałek, A. (2012). Analiza postaw przedsiębiorczych wśród studentów. E-mentor, 3(45), 25-34.

Okoń-Horodyńska, E. (2008). Edukacja dla innowacji. (Czy tylko wybrani skazani sa na sukces innowacyjny?). Nauka i Szkolnictwo Wyższe, 38(1), 34-54.

Olearnik, J. (2007). Obszary i formy działań uczelni dla wykształcenia przedsiębiorczego absolwenta. In: P. Wachowiak, M. Dąbrowski and B. Majewski (eds.), Ksztatcenie postaw przedsiębiorczych a edukacja ekonomiczna. Warszawa: Fundacja Promocji i Akredytacji Kierunków Ekonomicznych.

Osiri, J.K. and McCarty, M.M. (2013). Entrepreneurial Culture in institutions of higher education: impact on academic entrepreneurship. Journal of Entrepreneurship Education, 16, Special Issue, 4-11.

Pawlak, A. (2015). Wpływ rodziców-przedsiębiorców na wystepowanie intencji przedsiębiorczych u młodzieży szkół średnich w Polsce. Przedsiębiorczość $i$ Zarzadzanie, XVI(7[III]), 71-82.

Rachwal, T. and Wach, K. (2016). Badanie intencji przedsiębiorczych młodego pokolenia: wyniki ankietyzacji wśród studentów kierunków nieekonomicznych. Przedsiębiorczość-Edukacja, 12, 405-415.

Raport Ptacowy 2016. (2016). Hays Poland. Retrieved from http://www.hays.pl (10.07.2016).

Safin, K. (2014). Przedsiębiorcze zachowania studentów - stan i konsekwencje dla dydaktyki. Horyzonty Wychowania, 13(26), 327-340.

Shane, S. (2003). A General Theory of Entrepreneurship. The Individual - Opportunity Nexus. Cheltenham-Northampton: Edward Elgar. 
Shane, S. and Venkataraman, S. (2000). The Promise of Entrepreneurship as a Field of Research. Academy of Management Review, 25(1), 217-226.

Shattock, M. (2005). European universities for entrepreneurship: Their role in the Europe of knowledge. The theoretical context. Higher Education Management and Policy, 17(3), 13-25.

Starakiewicz, U. and Kubów, M. (2014). Przejawy przedsiębiorczości w sporcie w kontekście uwarunkowań kulturowych i organizacyjnych rozwoju branży. Horyzonty Wychowania, 13(28) 95-110.

Targalski, J. (2003). University Education for Entrepreneurship: Assumptions and Results. Cracow University of Economics Research Bulletin, 622, 21-28.
Tomski, P. (2015). Intencje przedsiębiorcze a płeć. Ku identyfikacji determinant. Przedsiębiorczość i Zarzadzanie, Vol. XVI, Section 7, Part III, 81-100.

Tuning (2006). Harmonisation of Educational Structures in Europe. Contribution of Universities to the Bologna Process. Education System Development Foundation. National Agency of "Life-long Learning” Program.

Wach, K. (2014). Edukacja dla przedsiębiorczości: pomiędzy przedsiębiorczą pedagogiką a edukacją ekonomiczną i biznesową. Horyzonty Wychowania, 13(28), 11-32.

Zbierowski, P. (2014). Determinanty intencji przedsiębiorczej studentów - wyniki badań. Horyzonty Wychowania, 13(28), 51-63. 